\title{
Peran Apoteker dalam Pengelolaan Penyakit Degeneratif di Dusun Mergan Sendangmulyo, Sleman, D.I. Yogyakarya
}

\author{
Dita Maria Virginia ${ }^{1}$, Aris Widayati ${ }^{2}$ \\ ${ }^{1}$ Program Studi S1 Ilmu Farmasi, Fakultas Farmasi, Universitas Sanata Dharma \\ ${ }^{2}$ Program Studi S2 Ilmu Farmasi, Fakultas Farmasi, Universitas Sanata Dharma \\ Email: virginia@usd.ac.id \\ https://doi.org/10.24071/altruis.2018.010109
}

\begin{abstract}
Findings of the preliminary survey showed a high proportion of geriatric people in Dusun Mergan, Sendangmulyo, Sleman, which leads to high risk of cardiovascular and other degenerative diseases. This community service program aimed to identify the health status of Mergan's people through health screening and to help them to maintain their health. This program was conducted in collaboration between the Faculty members and students of Pharmacy Faculty of Universitas Sanata Dharma Yogyakarta (USD). There were two consecutive periods; the first was in 7th of May and the second was in 22nd of October 2018. Health education, health screening, and health examination were conducted in each period. There were 93 people involved in the first period and 64 people in the second; however, only 32 persons who completely attended the two meeting periods. The program resulted data of $60.7 \%$ Mergan's people with a risk of dyslipidemia, and 59.0\% with hyperglycemic. There was no significant difference between the first and the second periods of examination of glucose level, cholesterol, and uric acid. Therefore, it is urgent to educate people in Mergan Village to promote and maintain a healthy lifestyle in order to decrease morbidity of degenerative disease in the community.
\end{abstract}

Keywords: monitoring, pengabdian, penyakit degeneratif, skrining

\section{PENDAHULUAN}

Dusun Mergan Sendangmulyo terletak di Kecamatan Minggir, Kabupaten Sleman, D.I. Yogyakarta, berjarak sekitar $25 \mathrm{~km}$ dari Kampus III Universitas Sanata Dharma. Hasil diskusi awal dengan Kepala Dusun mengindikasikan bahwa Dusun Mergan memiliki proporsi penduduk lanjut usia (lansia) yang tinggi yaitu $>35 \%$. Beberapa temuan awal menyebutkan bahwa penduduk banyak yang tidak pernah melakukan pemeriksaan asam urat, kolesterol ataupun glukosa. Hanya beberapa orang saja yang terkadang melakukan pemeriksaan tekanan darah. Puskesmas Pembantu (Pustu) berjarak sekitar $3 \mathrm{Km}$ dari Dusun Mergan, namun kendala transportasi dan usia merupakan salah satu alasan rendahnya kunjungan masyarakat ke Pustu untuk memeriksakan kesehatannya. Hal ini membutuhkan perhatian khusus karena tingginya risiko penyakit tidak menular yang dapat meningkatkan angka morbiditas dan atau mortalitas.

Penyakit tidak menular terutama penyakit degeneratif seperti hipertensi, dislipidemia, diabetes mellitus, dan hiperurisemia merupakan salah satu target sasaran Kementrian Kesehatan dalam meningkatkan derajat kesehatan masyarakat (Kementerian Kesehatan, 2013). Tingginya risiko dislipidemia, hipertensi, dan diabetes dapat meningkatkan risiko penyakit kardiovaskular (Alshehri, 2010). Kondisi hiperurisemia merupakan salah satu penyebab gout dan mengganggu aktivitas pasien karena rasa nyeri (Ragab dkk., 2017).

Skrining dan monitoring kesehatan dapat menjadi salah satu langkah preventif dan promotif dalam mengendalikan penyakit degeneratif (Center for Disease Control and Prevention, 2012). Pengobatan gratis dapat menjadi salah satu langkah kuratif yang efektif dalam pengendalian penyakit degeneratif, terutama di area terpinggir dan akses kesehatan terbatas.

Berdasarkan hal tersebut di atas, solusi yang ditawarkan kepada masyarakat Dusun Mergan yaitu: (1) penyuluhan kesehatan; (2) skrining kesehatan dan monitoring kadar kolesterol, asam urat, glukosa dan tekanan darah; (3) pengobatan gratis. Penyuluhan diberikan kepada seluruh masyarakat dengan penyuluhan lebih mendalam kepada kader sehat yang telah terbentuk.

Dusun Mergan merupakan salah satu dusun yang dipilih sebagai Desa Mitra Fakultas Farmasi Universitas Sanata Dharma. Pengabdian kepada masyarakat di Dusun Mergan ini bertujuan untuk 
melakukan skrining dan mengidentifikasi kondisi kesehatan masyarakat serta membantu memonitoring kesehatan masyarakat Dusun Mergan, terutama untuk mencegah peningkatan morbiditas penyakit degeneratif.

\section{METODE PELAKSANAAN}

Kegiatan ini merupakan suatu bentuk kolaborasi antara mahasiswa dan dosen Fakultas Farmasi Universitas Sanata Dharma dalam pengabdian di Desa Mitra. Sasaran kegiatan pengabdian kepada masyarakat ini yaitu masyarakat dewasa dan lansia di Dusun Mergan Sendangmulyo, Minggir, Kabupaten Sleman, D.I. Yogyakarta.

Kegiatan berlangsung dalam dua pertemuan, yaitu pertemuan pertama dilaksanakan tanggal 7 Mei 2017 dan pertemuan kedua pada tanggal 22 Oktober 2017. Pelaksanaan kegiatan ini terdiri dalam tiga bentuk kegiatan di tiap pertemuan, yaitu: (1) penyuluhan kesehatan; (2) skrining dan monitoring glukosa, kolesterol, asam urat, dan tekanan darah; dan (3) pengobatan gratis.

Penyuluhan dilakukan oleh seorang dosen FF USD (Apoteker). Penyuluhan diharapkan dapat membantu memberikan pengetahuan kepada kader di Dusun Mergan. Penyuluhan disertai pemberian booklet untuk disimpan peserta. Penyuluhan pertama mengenai diabetes mellitus dan penyuluhan kedua mengenai asam urat. Keduanya dilakukan oleh dosen FF USD (Apoteker). Pemilihan materi ini sesuai dengan permintaan Kepala Dusun. Durasi penyuluhan dan diskusi selama 1-1,5 jam.

Skrining dan monitoring tekanan darah dilakukan menggunakan tensimeter Omron ${ }^{\circledR}$. Pemeriksaan glukosa, asam urat, kolesterol menggunakan Easy touch ${ }^{\circledR}$. Masyarakat diminta untuk berpuasa selama 8-12 jam terlebih dahulu sebelum pemeriksaan kadar glukosa, kolesterol, dan asam urat. Kegiatan skrining dan monitoring dilakukan oleh mahasiswa FF USD. Pengobatan gratis melibatkan dua praktisi dokter serta dosen FF USD (Apoteker). Pengobatan gratis juga dibantu oleh mahasiswa FF USD yang disupervisi oleh dosen FF USD. Pelaksanaan kegiatan ini berlangsung selama 3-4 jam.

Jumlah masyarakat yang terlibat pada kegiatan pertama sebanyak 93 orang dan pada kegiatan kedua sebanyak 64 orang. Total data dari peserta yang terkumpul dari pertemuan pertama dan kedua sebanyak 122 orang. Namun demikian, total peserta yang secara komplit datang pada pertemuan pertama dan kedua sebanyak 32 orang.

Keberhasilan program pengabdian ini dilihat dari dua indicator, yaitu: (1) ketersediaan data skrining kondisi masyarakat dusun Mergan, (2) ketersediaan data monitoring kesehatan masyarakat. Analisis univariat dilakukan untuk mengidentifikasi hasil skrining awal terkait dengan prevalensi risiko penyakit degeneratif. Untuk melihat keberhasilan program ini dilakukan analisis bivariate dengan membandingkan nilai kadar glukosa, kolesterol, asam urat, dan tekanan darah menggunakan uji t-test berpasangan.

\section{HASIL DAN PEMBAHASAN}

\section{Kegiatan penyuluhan kesehatan}

Respon masyarakat yang terlibat dalam penyuluhan positif ditandai adanya beberapa pertanyaan dari peserta penyuluhan. Beberapa pertanyaan yang muncul dalam diskusi topik diabetes mellitus antara lain: (1) penggunaan insulin; (2) bagaimana bila terjadi penurunan kadar glukosa (hipoglikemia); (3) olahraga yang disarankan untuk pencegahan diabetes. Pertanyaan yang muncul pada topik penyuluhan mengenai asam urat yaitu: (1) pola makan pada penderita asam urat dan bagaimana mengatasi kekakuan sendi; (2) obat herbal yang disarankan untuk penderita asam urat.

Pada saat proses penyuluhan terjadi interaksi antara pembicara dengan peserta mengenai obat yang dikonsumsi pasien atau keluarganya. Dari kegiatan penyuluhan ini dapat dikatakan bahwa kader sehat di Dusun Mergan belum memiliki pengetahuan yang cukup mengenai

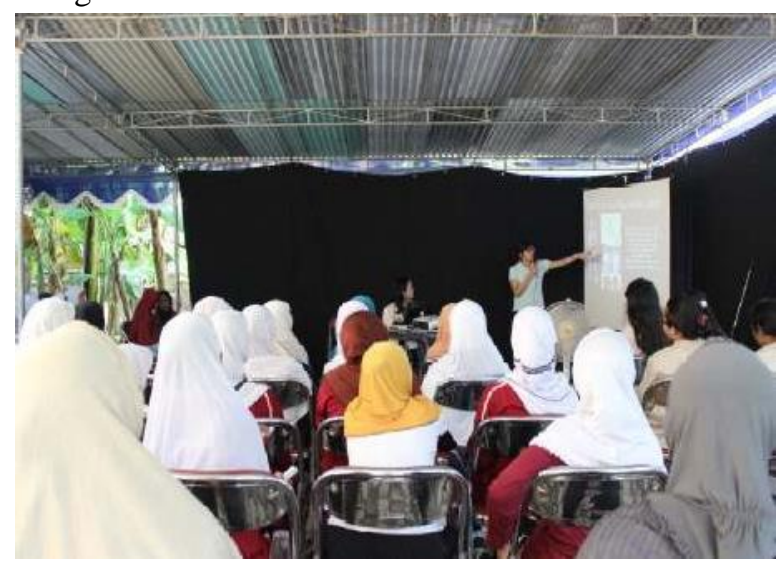

Gambar 1. Penyuluhan kepada Masyarakat Dusun Mergan

\section{Kegiatan skrining dan pemeriksaan kesehatan}

Tabel 1 menunjukkan proporsi lansia di Dusun Mergan yang cukup tinggi yaitu $45,1 \%$, dengan dominasi wanita sebesar $70,5 \%$, dan pekerjaan sebagai ibu rumah tangga sebesar 63,9\%. Tingginya proporsi masyarakat lanjut usia di Dusun Mergan membutuhkan perhatian tersendiri terutama karena orang lanjut usia secara fisiologis mengalami penurunan fungsi organ yang meningkatkan risiko morbiditas penyakit degeneratif (Lunenfeld and Stratton, 2013). 
Tabel 1. Karakteristik Masyarakat Dusun Mergan yang Terlibat dalam Kegiatan Desa Mitra Fakultas Farmasi Universitas Sanata Dharma 2017

\begin{tabular}{|c|c|c|}
\hline Karakteristik & Mean+SD & $\mathrm{N}=122 ;(\%)$ \\
\hline Usia (tahun) & \multirow{4}{*}{58,58} & \\
\hline$\leq 40$ & & $15(12,3)$ \\
\hline $40-60$ & & $52(42,6)$ \\
\hline$>60$ & & $55(45,1)$ \\
\hline \multicolumn{3}{|l|}{ Jenis kelamin } \\
\hline Perempuan & \multirow[t]{2}{*}{-} & $86(70,5)$ \\
\hline Laki-laki & & $36(29,5)$ \\
\hline \multicolumn{3}{|l|}{ Pekerjaan } \\
\hline Ibu rumah tangga & \multirow{4}{*}{-} & $78(63,9)$ \\
\hline Petani & & $32(26,2)$ \\
\hline Wiraswata & & $11(9,0)$ \\
\hline PNS & & $1(0,8)$ \\
\hline \multicolumn{3}{|l|}{ Tekanan darah $(\mathrm{mmHg}) *$} \\
\hline$\leq 140 / \leq 90$ & $133,8 \pm 21,0 /$ & $86(70,5)$ \\
\hline$>140 />90$ & $77,3+13,5$ & $36(29,5)$ \\
\hline \multicolumn{3}{|l|}{ Asam urat $(\mathrm{mg} / \mathrm{dL}) *(* *)$} \\
\hline Normal & $5,5 \pm 1,6$ & $90(73,8)$ \\
\hline Tinggi & & $32(26,2)$ \\
\hline \multicolumn{3}{|l|}{ Kolesterol (mg/dL)* } \\
\hline$<200$ & $228,7 \pm 73,7$ & $54(44,3)$ \\
\hline$>200$ & & $68(60,7)$ \\
\hline \multicolumn{3}{|l|}{ Glukosa $(\mathrm{mg} / \mathrm{dL})^{*}$} \\
\hline$<110$ & $131,0 \pm 61,1$ & $50(41,0)$ \\
\hline$>110$ & & $72(59,0)$ \\
\hline
\end{tabular}

Program pengabdian ini berhasil menjawab kebutuhan Dusun Mergan dalam hal skrining dan monitoring kesehatan masyarakat terkait penyakit degeneratif. Hasil skrining terlihat pada Tabel 1 yang menunjukkan 29,5\% memiliki tekanan darah >140/>90 mmHg. Sebesar 26,2\% masyarakat dalam kondisi hiperurisemia, 60,7\% terdektesi memiliki kadar kolesterol $\geq 200 \mathrm{mg} / \mathrm{dL}$, dan 59,0\% memiliki kadar glukosa $\geq 110 \mathrm{mg} / \mathrm{dL}$. Hiperlipidemia dan hiperglikemia memiliki proporsi lebih dari $50 \%$.

Hasil wawancara pada beberapa peserta kegiatan ini menunjukkan tingginya konsumsi makanan yang mengandung kolesterol serta rendahnya aktivitas fisik dapat menjadi penyebab tidak terkontrolnya kadar kolesterol. Tingginya kadar kolesterol merupakan salah satu risiko besar untuk penyakit kardiovaskular (Nelson, 2013).

Kadar glukosa $\geq 110 \mathrm{mg} / \mathrm{dL}$ merupakan suatu tahap prediabetes yang membutuhkan intervensi perubahan gaya hidup sebagai bentuk preventif diabetes (American Diabetes Association, 2017). Beberapa pernyataan pasien, khususnya pasien lansia, menyebutkan mereka jarang melakukan pemeriksaan kesehatan terkait kadar glukosa. Beberapa juga menyebutkan warga di Dusun Mergan memiliki riwayat keluarga penyakit Diabetes Mellitus. Banyak penelitian yang telah memastikan bahwa genetika merupakan faktor risiko Diabetes Mellitus selain gaya hidup (Das dkk., 2012).

Pada awal diskusi dimulainya Program Desa Mitra, Kepala Dusun menduga bahwa kemungkinan kondisi kesehatan masyarakat yaitu mengalami kadar glukosa dan asam urat yang tinggi. Namun sepertinya masyarakat tidak mengetahui dengan pasti karena mereka jarang melakukan pengecekan kesehatan ke Puskesmas. Berdasarkan hal tersebut hasil skrining ini mampu memberikan informasi kepada masyarakat dan Kepala Dusun untuk dapat ditindaklanjuti.

Hasil wawancara juga menunjukkan bahwa masih banyak masyarakat yang belum terdaftar dalam Jaminan Kesehatan Nasional. Hal ini juga seharusnya menjadi perhatian khusus untuk meningkatkan derajat kesehatan masyarakat Dusun Mergan.

\section{Kegiatan pengobatan gratis}

Pengobatan gratis yang dilaksanakan dalam dua pertemuan merupakan langkah kuratif. Pengobatan gratis yang dilakukan tidak khusus untuk penyakit kronis, namun melayani seluruh masyarakat yang membutuhkan terapi. Apoteker memberikan pelayanan informasi obat baik nonfarmakologi maupun farmakologi kepada pasien pada saat proses pengobatan gratis ini. Pemberian informasi obat yang dilakukan oleh Apoteker diharapkan 
dapat memberikan informasi mengenai gaya hidup sehat untuk memperbaiki kondisi pasien dan mencegah munculnya penyakit degeneratif.

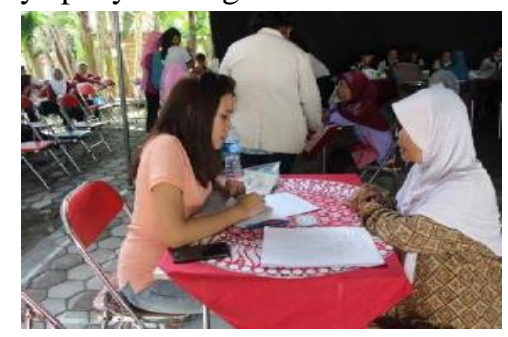

Gambar 2. Pengobatan Gratis Bagi Masyarakat Dusun Mergan

Gambaran perbedaan kondisi kesehatan masyarakat
Desa Mergan pada kegiatan pertama dan kedua
Hasil monitoring tekanan darah, kadar kolesterol, asam urat dan glukosa antara pertemuan pertama dan kedua dapat dilihat pada Tabel 2. Hasil tersebut menunjukkan tidak ada perbedaan bermakna antara kadar asam urat, kolesterol dan glukosa antara pertemuan pertama dan pertemuan kedua. Namun, hasil rerata menunjukkan kadar kolesterol dan kadar glukosa lebih rendah pada pertemuan kedua dibanding pertemuan pertama. Hal ini mungkin dapat disebabkan adanya terapi yang diperoleh pada saat kegiatan pengobatan gratis pertama. Belum bermaknanya perbedaan dapat dioptimalisasi dengan perubahan gaya hidup serta terapi rutin

Tabel 2. Perbedaan Antara Tekanan Darah, Kadar Glukosa, Asam Urat Dan Kolesterol Sebagai Hasil Monitoring Kegiatan Desa Mitra

\begin{tabular}{lccc}
\hline \multicolumn{1}{c}{ Karakteristik } & Pertemuan 2 & n \\
\cline { 1 - 2 } Tekanan darah sistolik $(\mathrm{mmHg})$ & $130,5 \pm 15,4$ & $137,5 \pm 17,1$ & 0,045 \\
\hline Tekanan darah sistolik $(\mathrm{mmHg})$ & $74,4 \pm 12,9$ & $81,2 \pm 14,1$ & 0,003 \\
\hline Asam urat $(\mathrm{mg} / \mathrm{dL})$ & $5,4 \pm 1,3$ & $5,4 \pm 1,3$ & 0,575 \\
\hline Kolesterol $(\mathrm{mg} / \mathrm{dL})$ & $227,9 \pm 70,3$ & $235,2 \pm 65,4$ & 0,459 \\
\hline Glukosa $(\mathrm{mg} / \mathrm{dL})$ & $132,3 \pm 53,0$ & $122,5 \pm 50,3$ & 0,179
\end{tabular}

Pada Tabel 2 juga menunjukkan adanya perbedaan bermakna tekanan darah, baik sistolik ataupun diastolik, dimana hasil pengukuran kedua lebih tinggi dibandingkan pengukuran pertama. Namun, nilai rerata sistolik masih kurang dari $140 \mathrm{mmHg}$ dan diastolik kurang dari $90 \mathrm{mmHg}$. Peningkatan tekanan darah dapat dipengaruhi oleh beberapa hal seperti stress, kurang tidur, ataupun pengukuran langsung setelah beraktivitas.

Pengobatan gratis dalam kegiatan ini sebagai langkah kuratif namun tidak efektif untuk progresivitas program karena terapi yang diberikan hanya satu minggu. Masyarakat telah diedukasi untuk melanjutkan terapi dengan pergi ke Pustu, namun hasil wawancara pada pertemuan kedua menunjukkan masyarakat berhenti terapi dan tidak kontrol ke Pustu.

Kegiatan ini berhasil menjawab permasalahan dengan memperoleh data hasil skrining dan monitoring status kesehatan. Hasil monitoring menunjukkan risiko penyakit degeneratif yang masih tetap tinggi di kalangan masyarakat Dusun Mergan. Oleh karena itu perlu adanya tindak lanjut seperti pembentukan kader ataupun pendampingan berkesinambungan dengan melibatkan pihak Pustu untuk memfasilitasi masyarakat untuk dapat mudah berobat ke Pustu. Hal lain yang dapat dilakukan yaitu memfasilitasi warga untuk mendaftar JKN agar mempermudah dan meringankan biaya terapi.
Kegiatan Pengabdian kepada Masyarakat ini menjadi suatu langkah awal bagi pemerintah desa dan masyarakat setempat dalam mengetahui kondisi kesehatanya khususnya mengenai penyakit degeneratif. Pengetahuan ini hendaknya menginduksi kesadaran masyarakat untuk mengubah gaya hidup serta melakukan pemeriksaan kesehatan rutin ke layanan kesehatan terdekat.

\section{KESIMPULAN DAN SARAN}

\section{Kesimpulan}

Kegiatan Pengabdian kepada Masyarakat ini berhasil memperoleh data skrining dan monitoring tekanan darah, kadar glukosa, kolesterol dan asam urat masyarakat Dusun Mergan yang terlibat, yaitu lebih dari $50 \%$ masyarakat terindikasi hiperlipidemia dan hiperglikemia.

\section{Saran}

Perlu adanya pembinaan lebih lanjut dan sistematis dengan berkolaborasi bersama pihak Puskesmas, serta memfasilitasi masyarakat untuk bergabung dalam program Jaminan Kesehatan Nasional. 


\section{DAFTAR REFERENSI}

Kementerian Kesehatan RI. (2013). Riset Kesehatan Dasar. Jakarta: Badan Penelitian dan Pengembangan Kesehatan

American Diabetes Association. (2017). Standards of Medical Care in Diabetes-2017. The Journal of Clinical and Applied Research And Eduaction, 40(1), 33.

Alshehri, A.M. (2010). Metabolic syndrome and cardiovascular risk. J Family Community Med, 17(2), 73-78.

Nelson, R.H. (2013). Hyperlipidemia as a Risk Factor for Cardiovascular Disease. Prim Care, 40(1), 195-211.

Lunenfeld, B. and Stratton, P. (2013). The clinical consequences of an ageing world and preventive strategies. Best Prat Res Clin Obstet Gynaecol, 27(5), 643-659.

Ragab, G., Elshahalay, M., Bardin, T. (2017). Gout: An old disease in new perspective - A review. Journal of Advanced Research, 8(5), 495-511.

Center for Disease Control and Prevention. (2012). Chronic Disease Prevention and
Health Promotion Domains. Diakses 12 Desember 2017 dari https://www.cdc.gov/chronicdisease/about/f oa/docs/four-domains-nov2012.pdf

Das, M., Pal, S., and Ghosh, A. (2012). Family history of type 2 diabetes and prevalence of metabolic syndrome in adult Asian Indians. Journal of Cardiovascular Disease Research, 3(2), 104-108.

\section{UCAPAN TERIMA KASIH}

Terimakasih kepada Kepala Dukuh dan masyarakat Dusun Mergan atas partisipasi dan kerjasama dalam pengabdian ini.

Terimakasih kepada Indian dan Margaretta Kathy Primawati sebagai koordinator mahasiswa bidang pengabdian di Desa Mitra dan seluruh mahasiswa FF USD yang terlibat.

Terimakasih kepada Dr. Yustina Sri Hartini, Apt. dan Putu Dyana Christasani, M.Sc., Apt. atas perannya dalam sebagai pembicara dalam penyuluhan dan sebagai Apoteker dalam pengobatan gratis. 